\title{
Molecular and Morphological Characterization of Colaconema formosanum sp. nov. (Colaconemataceae, Rhodophyta) - A New Endophytic Filamentous Red Algal Species from Taiwan
}

\author{
Meng-Chou Lee ${ }^{1,2,3}$ and Han-Yang Yeh ${ }^{1, *(D)}$ \\ 1 Department of Aquaculture, National Taiwan Ocean University, Keelung City 20224, Taiwan; \\ mengchoulee@email.ntou.edu.tw \\ 2 Center of Excellence for Ocean Engineering, National Taiwan Ocean University, Keelung City 20224, Taiwan \\ 3 Center of Excellence for the Oceans, National Taiwan Ocean University, Keelung City 20224, Taiwan \\ * Correspondence: 20833001@mail.ntou.edu.tw; Tel.: +886-2-2462-2192 (ext. 5231)
}

check for updates

Citation: Lee, M.-C.; Yeh, H.-Y Molecular and Morphological Characterization of Colaconema formosanum sp. nov.

(Colaconemataceae, Rhodophyta) —A New Endophytic Filamentous Red Algal Species from Taiwan. J. Mar. Sci. Eng. 2021, 9, 809. https://doi.org/ 10.3390/jmse9080809

Academic Editors: Zhun Li and Bum Soo Park

Received: 12 June 2021

Accepted: 24 July 2021

Published: 27 July 2021

Publisher's Note: MDPI stays neutral with regard to jurisdictional claims in published maps and institutional affiliations.

Copyright: (c) 2021 by the authors. Licensee MDPI, Basel, Switzerland. This article is an open access article distributed under the terms and conditions of the Creative Commons Attribution (CC BY) license (https:/ / creativecommons.org/licenses/by/ $4.0 /)$.

\begin{abstract}
The genus Colaconema, containing endophytic algae associated with economically important macroalgae, is common around the world, but has rarely been reported in Taiwan. A new species, C. formosanum, was found attached to an economically important local macroalga, Sarcodia suae, in southern Taiwan. The new species was confirmed based on morphological observations and molecular analysis. Both the large subunit of ribulose-1,5-bisphosphate carboxylase/oxygenase $(r b c \mathrm{~L})$ and cytochrome c oxidase subunit I (COI-5P) genes showed high genetic variation between our sample and related species. Anatomical observations indicated that the new species presents asexual reproduction by monospores, cylindrical cells, irregularly branched filaments, a single pyrenoid, and single parietal plastids. Our research supports the taxonomic placement of $C$. formosanum within the genus Colaconema. This study presents the third record of the Colaconema genus in Taiwan.
\end{abstract}

Keywords: Acrochaetioid; Colaconema formosanum; COI-5P; Endophytic alga; Nemaliophycidae; $r b c \mathrm{~L}$; taxonomy

\section{Introduction}

Florideophyceae is the most speciose class in Rhodophyta (red algae), with about 6900 species distributed worldwide [1]. Nemaliophycidae is one of the most diverse subclasses among red algae [2], including small and filamentous algae, growing as epiphytes or endophytes attached to rocks, macroalgae, and some marine animals. Their reproduction occurs mainly by monosporangia, which exist widely in both marine and freshwater systems $[3,4]$.

At present, 11 orders are included in Nemaliophycidae: Acrochaetiales (Feldmann, 1953), Balbianiales (Sheath and Müller, 1999), Balliales (Choi et al., 2000), Batrachospermales (Pueschel and Cole, 1982), Colaconematales (Harper and Saunders, 2002), Corynodactylales (Saunders et al., 2017), Entwisleiales (Scott et al., 2013), Nemaliales (Schmitz, 1892), Palmariales (Guiry, 1978), Rhodachlyales (West et al., 2008), and Thoreales (Müller et al., 2002) [1]. Interestingly, due to the ambiguous taxonomy in previous morphological evidence, the term "Acrochaetioid algae" is currently used to indicate some genera within Nemaliophycidae, such as Acrochaetium Nägeli, Audouinella Bory, Balbiania Sirodot, Colaconema Batters, Grania (Rosenvinge) Kylin, Rhodochorton Nägeli, and Liagorophila Yamada, although it is only used to describe the morphological affinity rather than phylogenetic affinity [5,6].

Even though morphology alone provides limited information for taxonomy due to the simple vegetative and reproduction branches of the Acrochaetiales [7], some phenotypic and biological attributes remain reliable, such as: life cycle pattern, germination pattern 
(Type I, Type II), reproduction development, vegetative features (cell size, plastid morphology, number of pyrenoids), attachment type (epiphyte or endophyte), biochemical characteristics (phycoerythrin type), and even ultrastructural observations (pit plug) $[5,6,8]$. The distinguishable characteristics of genus Colaconema were proposed to be prostrate, irregular filaments; monosporangiate; cup-like cells at terminals and intercalares; an unfixed plastid in each cell; and a single or more pyrenoids per cell. Most of these characteristics are unchallenged but inaccurate, and this has been the case for decades $[7,9]$.

When the molecular phylogeny is considered, many species within Nemaliophycidae have obtained better taxonomic support. For instance, Lam et al. (2016) redefined the phylogeny of Nemaliophycidae using the $p s a \mathrm{~A}, p s b \mathrm{~A}, p s a \mathrm{~B}, \mathrm{EF} 2, c o x 1, c o b, 18 \mathrm{~S}$ rDNA, and $28 \mathrm{~S}$ rDNA genes [2]; Saunders et al. (2018) resolved the family level assignments of the Acrochaetiales-Palmariales complex using the mitochondrial cytochrome c oxidase 1 gene (COI-5P) [10]; Soares et al. (2020) established the new species Rhodachlya westii using the $r b c \mathrm{~L}$ gene [3]; Skriptsovar et al. (2020) assessed the phylogenetic relationships within Palmariaceae using the internal transcribed spacer (ITS) and $r b c$ L genes [11]; Araújo et al. (2014) and Montoya et al. (2020) identified the endophytic algae C. infestans and C. daviesii through morphology and $r b c \mathrm{~L}$ and COI-5P genes, respectively $[12,13]$.

Members of the order Colaconematales are usually epiphytes or endophytes and are only present in marine regions [7]. There are currently 51 taxonomically accepted species in the genus Colaconema, which has a circumtropical distribution [1]. Records have shown that the host selection mechanism of Colaconema species appears to be random, e.g., on Kappaphycus alvarezii (Doty) L.M. Liao, Chondracanthus chamissoi (C. Agardh) Kützing, and Nizamuddinia zanardinii (Schiffner) P.C. Silva [12-14]. The endophyte phenomenon negatively affects the host and is seen seasonally, however the invasion mechanism is not clear $[12,13]$.

Our observations in the field found an endophyte filamentous alga attached to Sarcodia suae S.-M.Lin \& C.Rodríguez-Prieto (Plocamiales), an economically important red alga in Taiwan, mainly as a foodstuff with abundant dietary fiber, nutrition, and antioxidants $[15,16]$.

However, there has been no information available about the endophyte algae from $S$. suae in Taiwan before. This study presents the third record of a Colaconema species in Taiwan (the other two species being C. secundatum (Lyngbye) Woelkerling and C. tenuissimum (Collins) Woelkerling) discovered attached to a local red alga of economic importance, $S$. suae. To fully understand the features of this endophytic alga, we conducted morphological and molecular analyses to clarify its taxonomic position.

\section{Materials and Methods}

Sample collection: Infected thalli of Sarcodia suae were collected at an intertidal zone in Wan-li-tong, Pingtung, Taiwan, in July $2014\left(21^{\circ} 59^{\prime} 41^{\prime \prime} \mathrm{N}, 120^{\circ} 42^{\prime} 22^{\prime \prime} \mathrm{E}\right)$.

Morphological studies: Samples of the endophytic filamentous algae were fixed in $4 \%$ formalin/seawater for morphological observations. Photomicrographs were obtained using an Olympus BX53 microscope (Olympus, Tokyo, Japan) with a DP72 digital camera and cellSens software (Olympus). The voucher specimens were deposited in the National Taiwan Ocean University (NTOU) Algal Cultivation and Biotech Laboratory, Taiwan.

Sample cultivation: Samples of endophytic isolates were cultured in the laboratory for 21 days to increase the algal biomass for molecular studies. The alga was cultured in a beaker with $800 \mathrm{~mL}$ Provasoli-enriched seawater (PES) culture medium [17] (sterilized) to which $\mathrm{GeO}_{2}\left(1 \mathrm{~mL} \mathrm{~L}{ }^{-1} \mathrm{PES}\right)$ was added to inhibit the growth of diatoms. The culture conditions were as follows: temperature of $25 \pm 2{ }^{\circ} \mathrm{C}$, salinity of $32 \pm 1 \mathrm{psu}$, and a 12:12 $\mathrm{h} \mathrm{light/dark} \mathrm{cycle} \mathrm{with} \mathrm{an} \mathrm{irradiance} \mathrm{of} 50 \mu \mathrm{mol}$ photons $\mathrm{m}^{-2} \mathrm{~s}^{-1}$ provided by $9 \mathrm{~W}$, 900 Lumen $6500 \mathrm{~K}$ white LED bulbs (Everlight, New Taipei City, Taiwan).

DNA extraction: Fragments of silica-dried thalli were ground in a sterile mortar with liquid nitrogen. Total genomic DNA was extracted from $40 \mathrm{mg}$ of algal tissue using the Wizard Genomic DNA Purification Kit (Promega, Madison, WI, USA) following the 
manufacturer's protocol, with minor modifications in centrifugation at $16,000 \times g$ for $10 \mathrm{~min}$ at $94{ }^{\circ} \mathrm{C}$ (Allegra X-12R; Beckman Coulter, La Brea, CA, USA), and in rehydration with $40 \mu \mathrm{L}$ Tris-EDTA buffer solution. The partial $r b c \mathrm{~L}$ gene was amplified with the primer pairs F7-R753, F645-R1150, and F449-RrbcSstart [18,19]. The COI-5P gene was obtained with the primer pair GazF1-GazR1 [20]. The PCR protocol consisted of $5 \mathrm{~min}$ at $96{ }^{\circ} \mathrm{C}$ for initial denaturation, followed by 35 cycles of $60 \mathrm{~s}$ at $94{ }^{\circ} \mathrm{C}, 60 \mathrm{~s}$ at $45^{\circ} \mathrm{C}$, and $90 \mathrm{~s}$ at $72{ }^{\circ} \mathrm{C}$, with a final extension for $8 \mathrm{~min}$ at $72{ }^{\circ} \mathrm{C}$, and then a soaking cycle at $15{ }^{\circ} \mathrm{C}$. The PCR product was purified with the QIAquick PCR Purification Kit (Qiagen, Hilden, Germany). Commercial sequencing was performed using the Taq Big Dye Terminator Cycle Sequencing Kit (Applied Biosystems, Foster City, CA, USA). The forward and reverse primers used for sequencing were the same as those used for PCR amplification.

Phylogenetic analysis: We obtained the DNA sequences of the $r b c \mathrm{~L}$ and COI-5P genes from the unknown endophytic alga in this study; other sequences were retrieved from GenBank, which included the species from the order Colaconematales and the order Acrochaetiales (Balliales, Batrachospermales, Entwisleiales, Nema-liales, Palmariales, and Thoreales). All new sequence data generated from this study were deposited in GenBank, with the following accession numbers: MH414967, MW182306-MW182308 ( $r b c \mathrm{~L})$; and MW182302-MW182305 (COI-5P). The sequences were aligned with multiple sequence alignment (MUSCLE) [21] using MEGA v10.1 [22], then checked and trimmed by eye using BioEdit 7.1.3.0 [23]. IQ-TREE software [24] was used to select the best model of evolution, as inferred from the implementation of the Bayesian Information Criterion (BIC) and Akaike Information Criterion (AIC). The best-selected models for the $r b c \mathrm{~L}$ and COI-5P sequences were GTR+F+I+G4 and TIM2+F+I+G4, respectively. The IQ-TREE program was used to perform maximum-likelihood (ML) phylogenetic inference and the results were displayed using FigTree v. 1.4.0 software [25]. Statistical support was assessed with 1000 bootstrap replications [26]. The Bayesian inference (BI) was conducted with MrBayes 3.2.7 [27] and followed the best models identified above. Two independent runs of four chains of Markov Chain Monte Carlo (MCMC) were conducted, with one tree sampled every 100 generations for one million generations. The results of the generations were used to build the consensus tree.

\section{Results}

\subsection{Phylogenetic Results}

The final $r b c \mathrm{~L}$ alignment included 1202 nucleotides and 68 sequences, including four new Colaconema sp. specimens (MH414967, MW182306-MW182308). The final COI$5 \mathrm{P}$ dataset included 582 nucleotides and 57 sequences, including sequences from four new Colaconema sp. specimens (MW182302-MW182305). Both ML and BI had virtually congruent topologies, thus, the ML consensus tree was used and the BI values were plotted on the nodes. The unknown species belonged to the order Colaconematales, forming a monophyletic clade with high support $(r b c \mathrm{~L}: \mathrm{ML}=80 \%, \mathrm{BI}=1.00$; COI-5P: $\mathrm{ML}=92 \%$, $\mathrm{BI}=0.99$ ).

In the rbcL phylogeny (Figure 1), C. formosanum was sister to C. savianum (DQ787561) from Korea in a fully supported clade; the genetic distance between C. formosanum and C. savianum was $7.19-7.83 \%$. For the COI-5P gene (Figure 2), C. formosanum was sister to two specimens of Colaconema sp. (HQ422955 and HQ422983) from USA with strong support $(\mathrm{ML}=91 \%, \mathrm{BI}=1.00)$. The genetic distance between $C$. formosanum and Colaconema sp. was $14.02-14.19 \%$. In this study, the morphological and molecular analyses supported the taxonomic position of this new filamentous red algal species from Taiwan. We therefore propose the new species, Colaconema formosanum. 


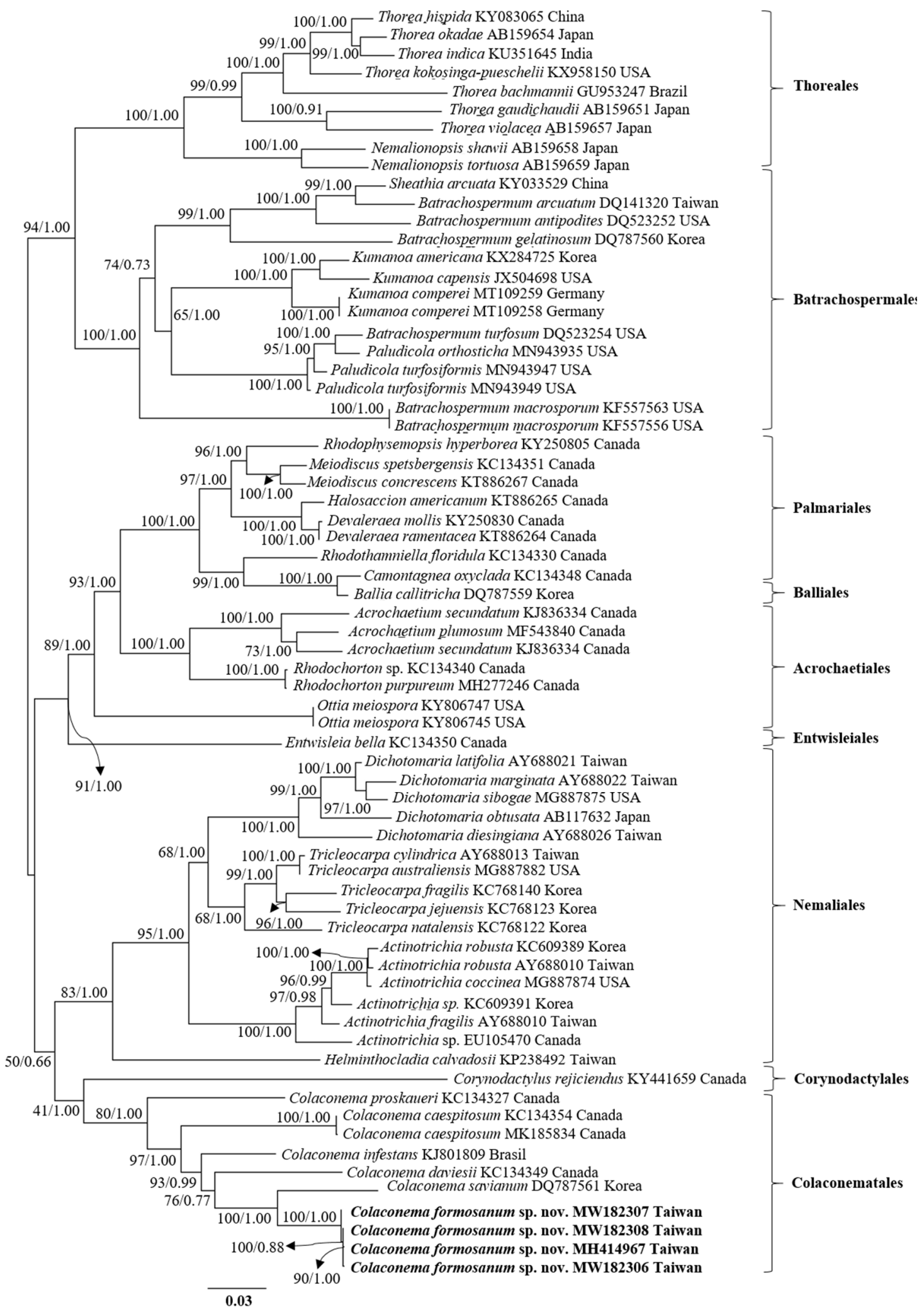

Figure 1. Maximum-likelihood (ML) phylogeny of Nemaliophycidae inferred from partial $r b c L$ sequences. Orders within Nemaliophycidae are represented. Values shown at the nodes indicated bootstrap support (BS) for ML and posterior probabilities (PP) for BI. The new species of this study (Colaconema formosanum sp. nov.) is shown in bold. 


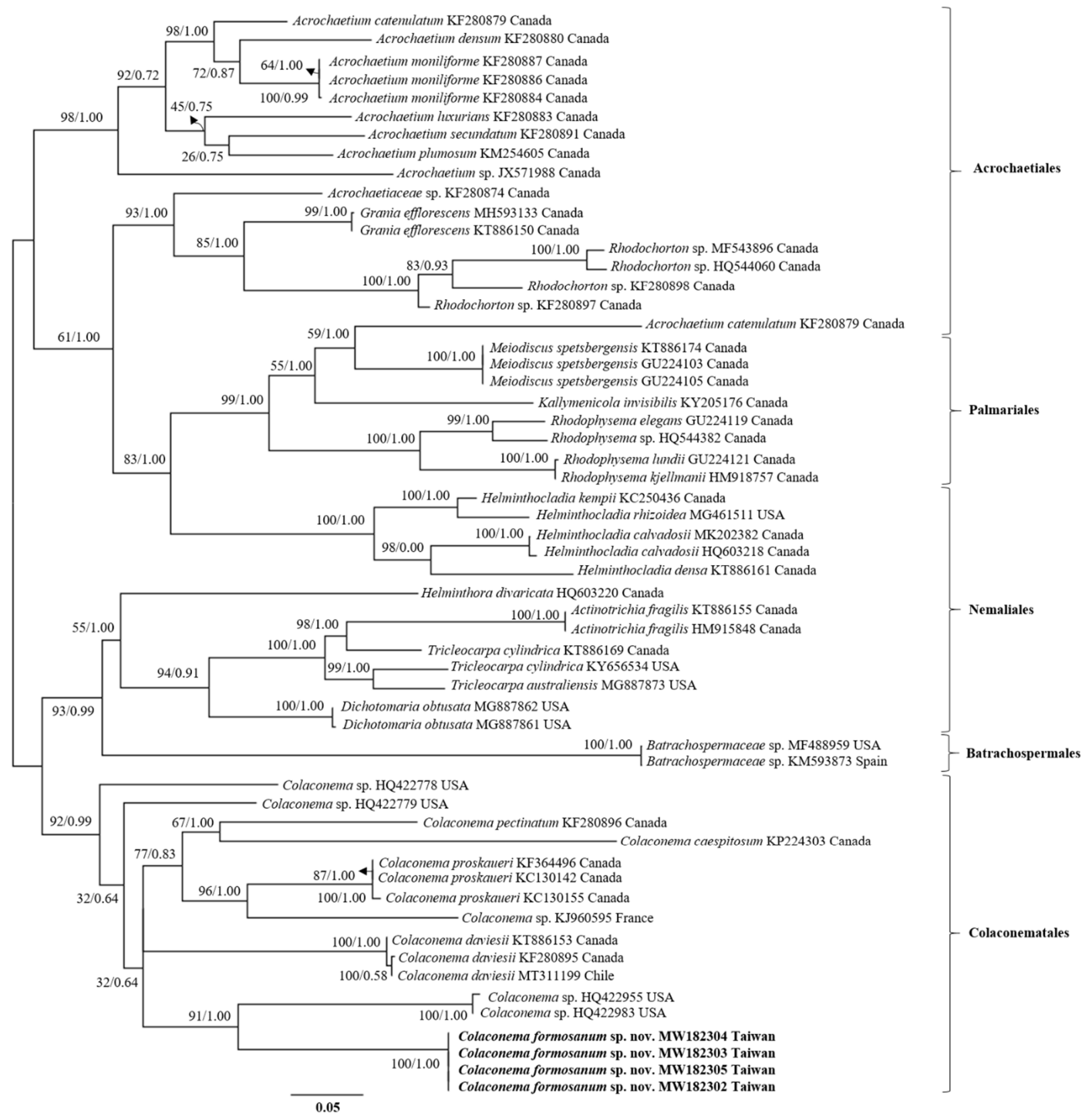

Figure 2. Maximum-likelihood (ML) phylogeny of Nemaliophycidae inferred from partial COI-5P sequences. Orders within Nemaliophycidae are represented. Values shown at the nodes indicated bootstrap support (BS) for ML and posterior probabilities (PP) for BI. The new species of this study (Colaconema formosanum sp. nov.) is shown in bold.

\subsection{Morphological and Culture Analyses}

Colaconema formosanum M.-C. Lee, H.-Y. Yeh sp. nov.

Diagnosis: Filamentous endophytic thalli infected Sarcodia suae between its cortical and subcortical cells. Erect axes forked several times, producing irregular filaments. Oval monospores borned on the terminal cells.

Holotype: Voucher number-NTOU LMC CF2101 (deposited in Algal Cultivation and Biotech Laboratory, Department of Aquaculture, National Taiwan Ocean University, Taiwan), collected by M.-C. Lee \& H.-Y. Yeh on 10 July 2014 at Wan-li-tong, Pingtung, endophytic on the red alga Sarcodia suae (Figure 3A-D). $r b c$ L sequence $=$ GenBank accession MH414967; COI-5P sequence $=$ GenBank accession MW182302. 


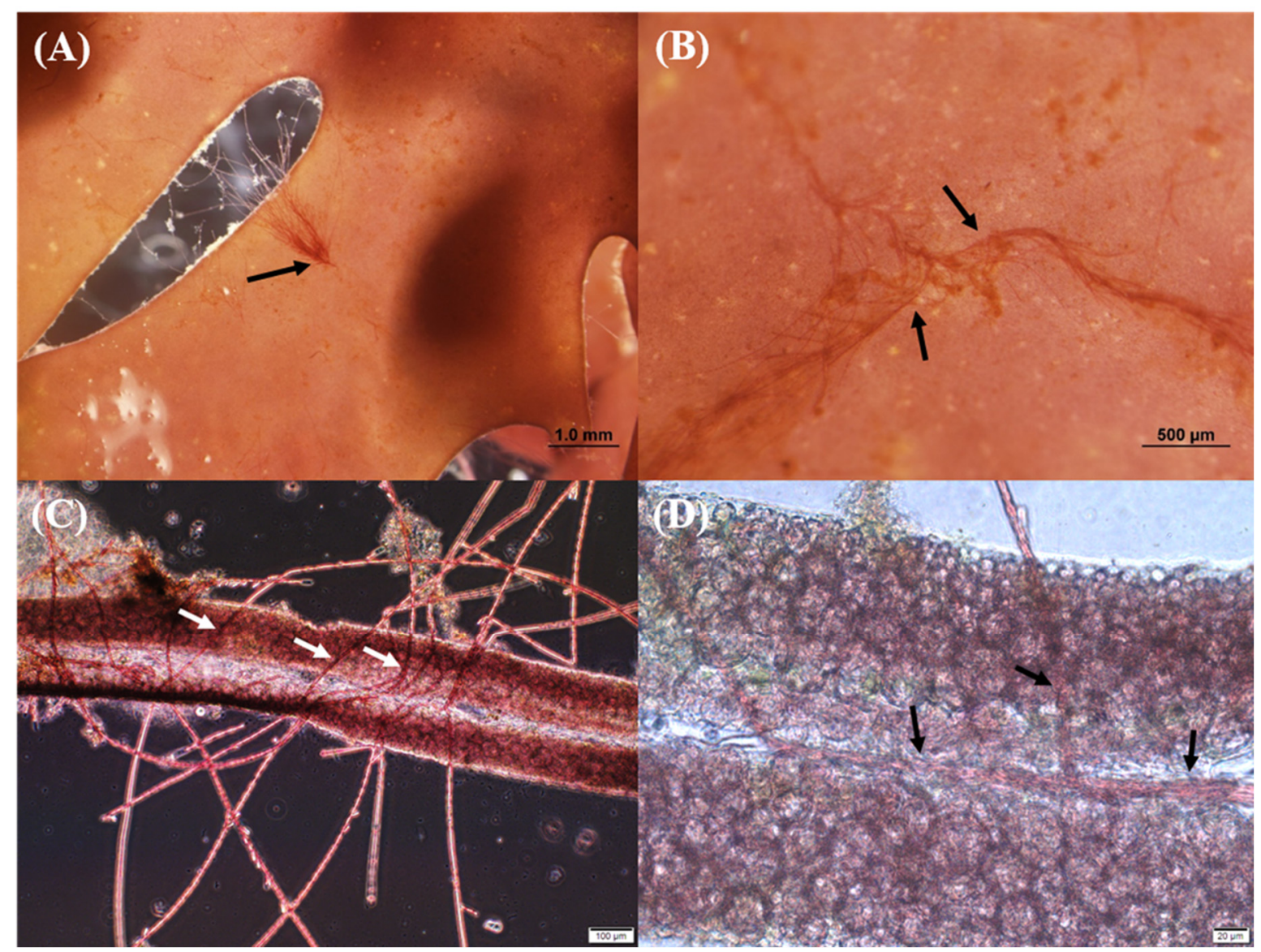

Figure 3. Colaconema formosanum sp. nov. (A,B) Thalli endophytic on Sarcodia suae (arrows). (C,D) Transversal sections of $S$. suae showing partially endophytic thalli of C. formosanum growing between cortical and subcortical cells (arrows).

Isotype: NTOU LMC CF0002- CF0004, deposited in NTOU, Taiwan. rbcL sequences = GenBank accession MW182306, MW182307, and MW182308, respectively; COI-5P sequences = GenBank accession MW182303, MW182304, and MW182305, respectively.

Type locality: Wan-li-tong, Ping-tung, Taiwan $\left(21^{\circ} 59^{\prime} 43^{\prime \prime} \mathrm{N}, 120^{\circ} 42^{\prime} 16^{\prime \prime} \mathrm{E}\right)$.

Etymology. The specific epithet, formosanum, is derived from a Latin and Portuguese noun meaning beautiful, which was a former name of Taiwan. Herein, the meaning is that the species is from Taiwan.

Chinese name: 臺灣寄絲藻

Distribution: The type locality is in the intertidal zone of Ping-Tung City, Taiwan, the species is known only from the type locality.

Habitat: Filamentous thalli endophytic on the marine red alga Sarcodia suae.

\subsection{Vegetative Morphology}

The thalli formed clusters of red to deep-red filaments, $2.0-2.8 \mathrm{~cm}$ long, arising from a basal disc (Figure 4A,B). Erect axes were pseudodichotomous, branching at irregular segments (Figure 4A). Each cylindrical cell was 6.0-7.5 $\mu \mathrm{m}$ wide and 12.5-15 $\mu \mathrm{m}$ long (Figure $4 \mathrm{D}$ ). Segment length to diameter (L:D) ratios at lower and mid-branch positions and towards apices were 1.6:1.8, 4.0:4.2, and 3.7:3.9, respectively (Figure 4D). Cells with a single pyrenoid, and single parietal or lobed plastids (Figure 4D). The endophytic cells showed the ability to completely penetrate into the cortical and subcortical cells of $S$. suae (Figure 3C,D). 


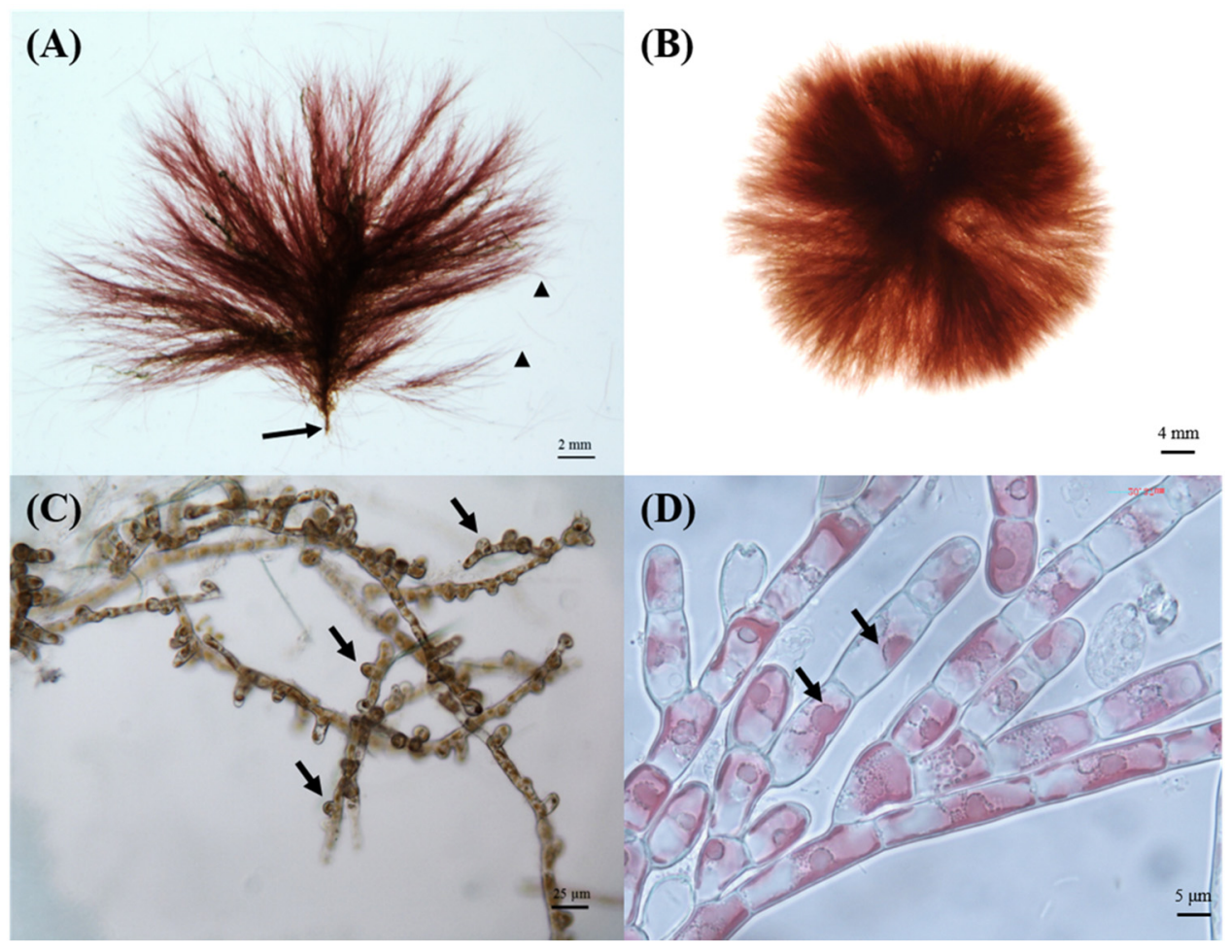

Figure 4. Colaconema formosanum sp. nov. (A) General aspect of a tuft showing erect filaments (arrowheads) formed from a basal disc (arrow). (B) Concentric tufts formed under culture conditions. (C) Monosporangia (arrows) formed on prostrate cultured thallus. (D) Detail of erect filaments showing cells with one pyrenoid (arrows).

\subsection{Reproductive Morphology}

Monosporangia were observed only on the apical cells of the lateral branch, solitary or in clusters. The monosporangia were subspherical, 12-13 $\mu \mathrm{m}$ long and 9.5-10 $\mu \mathrm{m}$ wide (Figure 5A). Upon maturity, the monospores were released from the monosporangia (Figure 5B,C), and some paraphyses could be seen on the apical portion of the monosporangia (Figure 5D). The released monospores exhibited a circular shape, 9-10 $\mu \mathrm{m}$ in diameter at the initial stage (Figure 6A). After $24 \mathrm{~h}$, a tube-like cell emerged and elongated gradually (Figure 6B,C). After 2 to 3 days under culture conditions, a second set of segments was observed (Figure 6D). An apical part of the cell released a mucus-like matrix at this stage that engulfed all surrounding filaments, and a filamentous growth form was observed (Figure 6E). Male and female structures could not be distinguished. 


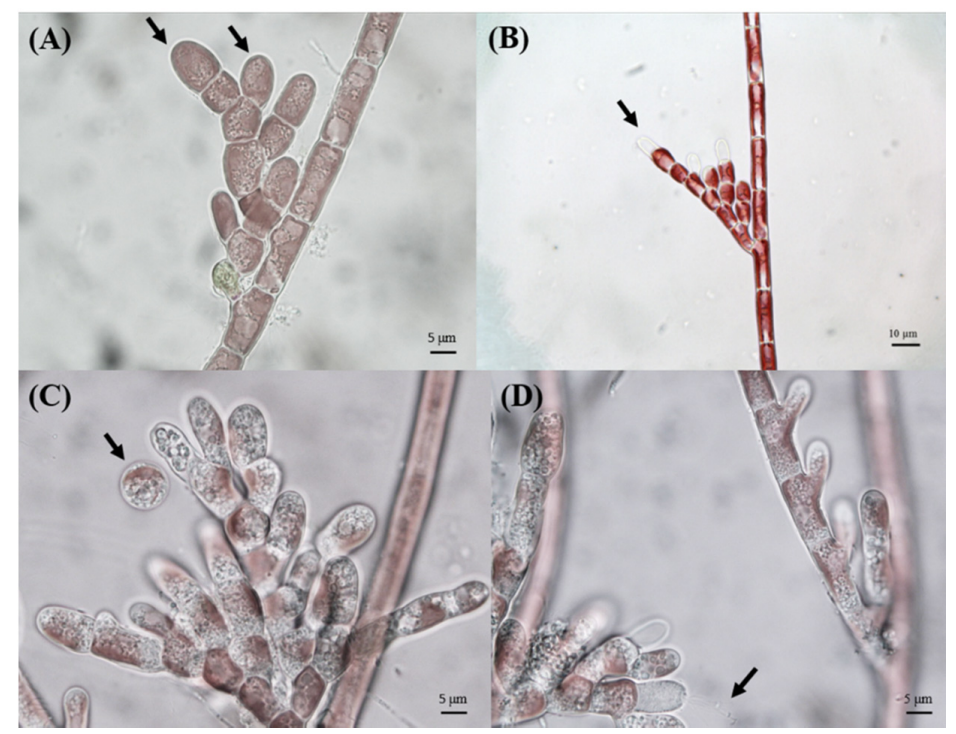

Figure 5. The process of monospore release of Colaconema formosanum sp. nov. (A) Mature monosporangia (arrow). (B) After monospore release, only the cell wall persists (arrow). (C) Monospore released from monosporangia (arrow). (D) When the monospore is released, paraphyses are formed from the monosporangia (arrow).

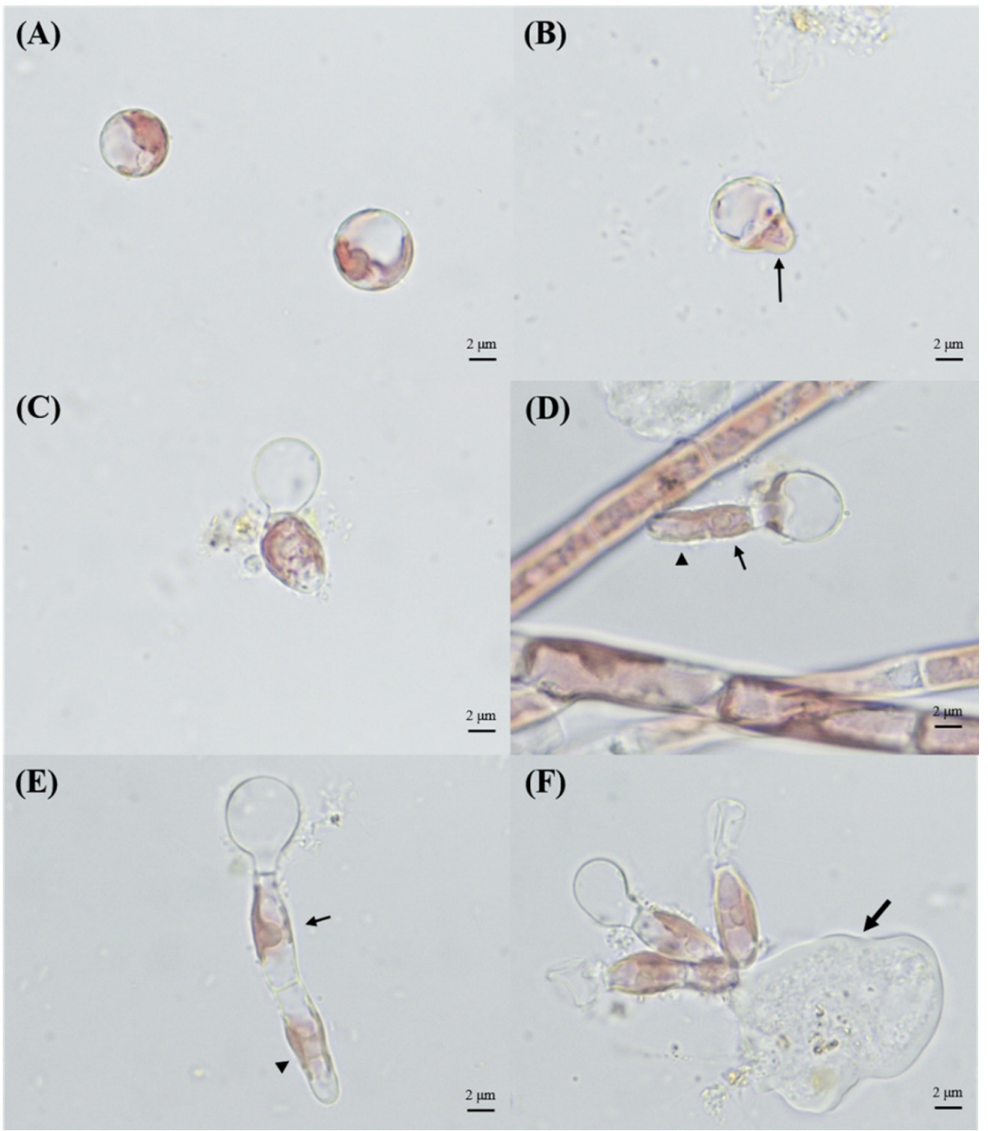

Figure 6. Sporeling development in Colaconema formosanum sp. nov. (A) Newly released spores had a concentric circular shape. (B,C) After $24 \mathrm{~h}$, a tube-like cell emerged from the spore and gradually expanded. (D,E) After 2 to 3 days under culture conditions, a second cell could be clearly observed (arrow $=$ first cell, arrow head $=$ second cell). $(\mathbf{F})$ The apical part of the cell in this stage released a mucus-like matrix (arrow). 


\section{Discussion}

Due to the close relationship among species within Nemaliophycidae lines, it is a taxonomic conundrum if only relying on morphology. Even though this has led to a long standing debate on over-relying on morphological attributes within Nemaliophycidae, some features of algae are still worth evaluating [8]. In this study, C. formosanum showed some typical features of the Colaconema genus, e.g., monosporangia, cylindrical cells, irregularly branched filaments, a single pyrenoid, and single parietal or lobed plastids. In addition, we found that the phycoerythrin of $C$. formosanum was of R-type (un-published data), meanwhile, the germination form was type II, meaning that when the germ tube developed, the protoplast was retained [7], which was similar to C. daviesii but is mentioned for the first time in Colaconema genus. We recommend tracing this feature in further studies. The morphological evidence supports $C$. formosanum as a new species.

Since few reports investigate the detailed morphological features of Colaconema species, only $C$. daviesii and C. infestans would be explored in this study, and we mainly focus on cell type, monosporangia, number of pyrenoids, number of plastids and spore germination $[12,13]$. However, C. formosanum can be differentiated from $C$. infestans by larger thallus size (C. formosanum 20-250 mm; C. infestans $5 \mathrm{~mm}$ ) and cell dimensions (C. formosanum 6-7.5 $\mu \mathrm{m}$ in diameter and $12-15 \mu \mathrm{m}$ in length; $C$. infestans $2.4-6.4 \mu \mathrm{m}$ in diameter and $10-17.6 \mu \mathrm{m}$ in length) (Table 1).

Table 1. Comparison of morphological and anatomical characteristics among Colaconema formosanum and the other closely related filamentous Colaconema species.

\begin{tabular}{cccc}
\hline Characters & C. formosanum & C. daviesii & C. infestans \\
\hline Habit & Marine & Marine & Marine \\
Host & Sarcodia suae & Chondracanthus chamissoi & Kappaphycus alvarezii \\
Thallus long $(\mathrm{mm})$ & $20-250$ & - & 5 \\
Cell dimensios $(\mu \mathrm{m})$ & $6-7.5 \times 12-15$ & - & $2.4-6.4 \times 10-17.6$ \\
Cell type & Cylindrical & Cylindrical & Sylindrical \\
Monosporangia & Subspherical, solitary or in clusters & Subspherical & Single \\
Pyrenoid & Single & - & Single parietal \\
Plastid & Single parietal & - & - \\
Spore $(\mu \mathrm{m})$ & $9-10$ & - & - \\
Spore germination & Type II & Type II & - \\
Phycoerythrin type & $\mathrm{R}$ & - & Pitimbu, Brazil \\
Type locality & Ping-Tung, Taiwan & Bio-Bio, Chile & {$[12]$} \\
References & This study & & \\
\hline
\end{tabular}

Although the features above are sufficient to satisfy the taxonomic requirements of the monophyly of Colaconema genus and meanwhile show the specific position of the new species [12-14], they still do not accurately confirm the taxonomy. In contrast, it has been demonstrated that the cell dimensions are affected by multiple environmental factors, making it hard to evaluate taxonomy using these features [3,28]. Consequently, molecular phylogenetics is a more reliable method to apply to taxonomy within Nemaliophycidae.

Molecular assisted identification with plastid-encoded $r b c \mathrm{~L}$ and COI-5P have strongly helped in discriminating species of $C$. formosanum, although the information on divergences in Colaconema is poorly reported, it is useful to follow other cases, for instance, the $r b c \mathrm{~L}$ divergences between Halymenia species are reported to be $0.7-10.6 \%$ [29]; the cox1 divergences between Gelidium species are reported to be $2.7-5.4 \%$ [30]. C. formosanum is well segregated from the C. savianum (DQ787561) and Colaconema sp. (HQ422955 and HQ422983) by pairwise divergences of $r b c \mathrm{~L}(7.19-7.83 \%)$ and cox1 (14.02-14.19\%), respectively. The results illustrate that the interspecific divergences of $C$. formosanum are sufficiently high to warrant $C$. formosanum as a new species.

It is not surprising that the Colaconema genus exhibits endophytic behavior, as other examples have been reported worldwide [12-14] (Table 1). Although those cases (for the 
Colaconema genus) only present on macroalgae, evaluating the endophytic phenomenon within other genera at the Nemaliophycidae level suggests that their host specificity may be ecologically determined, and there are reports of attachment to rocks, macroalgae, and some marine animals [31]. This is the first occurrence of an endophytic Colaconema species in the red alga S. suae in the intertidal zone of Taiwan. In order to reproduce the endophytic phenomenon to exclude the probability of coincidence, in our study we recreated the infection process under artificial culture conditions. When we co-cultured the endophytic C. formosanum and the host plant S. suae (without pollution), the endophytic phenomenon could be clearly observed under a dissecting microscope after five days of cultivation, indicating that the entire endophytic process occurs rapidly and easily (unpublished data).

The host may affect the life phases of an endophytic alga [32]. Interestingly, we found there was no temporal correlation between life phases of C. formosanum (endophytic alga) and S. suae (host alga), which was confirmed using purified cultures under laboratory conditions and observing the life phases of $C$. formosanum. This result is also supported by previous studies on other endophytic algae, for instance, Correa and McLachlan (1991) isolate Ulvella operculata and U. heteroclada from Chondrus crispus [33]; Gonzalez and Goff (1989) isolate Campylaephora californica and Microcladia coulteri from Egregia menziesii [34].

The probable mechanism, based on a previous study conducted on C. infestans, is that the infection changes the biosynthesis pathways of starch enzymes in the Calvin cycle of the host, activating the degradation pathway to produce certain defense compounds. One type of defense compound, uridine diphosphate glucose (UDP-glucose), induces the synthesis of cell wall components instead of floridean starch grains [35]. This phenomenon was also observed in our study; after the host was infected by C. formosanum, the growth performance decreased and the algal texture thickened compared with uninfected host samples. However, this observation should be confirmed by further studies.

Some records show that endophytic Colaconema species can attach to economically important macroalgae; the initial symptoms are tiny black spots on the surface of the cortical layer of the host, which subsequently become rough tufts. After an outbreak, host cells degrade, forming tiny pores, which allows secondary infection by opportunistic bacteria, with further negative effects on the host and impacts on the aquaculture industry [12,36]. We observed a similar phenomenon in the infection process in this study, but after infection the growth development of the host is unknown, and it would be worthwhile to investigate this further.

In summary, our molecular analysis and morphological observations support the identification of the new species $C$. formosanum This study is the first to describe this alga in Taiwan and report its endophytic habit, attaching to the edible alga $S$. suae. Its endophytic attachment phenomenon and life phases can be reproduced under laboratory conditions. A detailed investigation of the endophytic mechanisms that are generated between C. formosanum and S. suae and potential applications for this endophytic alga will be necessary topics to explore in future research.

Author Contributions: M.-C.L.: Methodology, Supervision, Funding acquisition. H.-Y.Y.: Methodology, Investigation, Formal analysis, Writing—review and editing, Writing—original draft, Resources. All authors contributed critically to the drafts. All authors have read and agreed to the published version of the manuscript.

Funding: Financial support for this study was mainly provided by a MOST research grant (108-28238-019-001).

Institutional Review Board Statement: Not applicable.

Informed Consent Statement: Not applicable.

Data Availability Statement: Not applicable.

Acknowledgments: The authors especially thank the editors and anonymous reviewers for their thoughtful comments. The authors special thanks to Showe-Mei Lin for assisting with DNA sequencing and morphological recognition, and Hsin-Fu Liu for assisting with the phylogenetic analysis. 
Conflicts of Interest: The authors declare that the research was conducted in the absence of any commercial or financial relationships that could be construed as a potential conflict of interest.

\author{
Abbreviations \\ COI-5P cytochrome c oxidase subunit I gene \\ ML maximum-likelihood \\ NJ neighbor-joining \\ PES Provasoli-enriched seawater \\ $r b c \mathrm{~L}$ ribulose-1,5-bisphosphate carboxylase/oxygenase
}

\title{
References
}

1. Guiry, G.M. AlgaeBase. World-Wide Electronic Publication, National University of Ireland, Galway. 2021. Available online: https: / / www.algaebase.org (accessed on 2 March 2021).

2. Lam, D.W.; Verbruggen, H.; Saunders, G.W.; Vis, M.L. Multigene phylogeny of the red algal subclass Nemaliophycidae. Mol. Phylogenet. Evol. 2016, 94, 730-736. [CrossRef] [PubMed]

3. Soares, L.P.; de Beauclair Guimarães, S.M.P.; Fujii, M.T.; Yoneshigue-Valentin, Y.; Batista, M.G.S.; Yokoya, N.S. Rhodachlya westii sp. nov. (Rhodachlyales, Rhodophyta), a new species from Brazil, revealed by an integrative taxonomic approach. Phycologia 2020, 59, 346-354. [CrossRef]

4. Saunders, G.W.; Hommersand, M.H. Assessing red algal supraordinal diversity and taxonomy in the context of contemporary systematic data. Am. J. Bot. 2004, 91, 1494-1507. [CrossRef] [PubMed]

5. Harper, J.; Saunders, G. A molecular systematic investigation of the Acrochaetiales (Florideophycidae, Rhodophyta) and related taxa based on nuclear small-subunit ribosomal DNA sequence data. Eur. J. Phycol. 1998, 33, 221-229. [CrossRef]

6. Woelkerling, W.J. The Audouinella (Acrochaetium-Rhodochorton) complex (Rhodophyta): Present perspectives. Phycologia 1983, 22, 59-92. [CrossRef]

7. Harper, J.T.; Saunders, G.W. A re-classification of the Acrochaetiales based on molecular and morphological data, and establishment of the Colaconematales ord. nov. (Florideophyceae, Rhodophyta). Eur. J. Phycol. 2002, 37, 463-476. [CrossRef]

8. Garbary, D.; Gabrielson, P. Acrochaetiales (Rhodophyta): Taxonomy and evolution. Cryptogam. Algol. 1987, 8, $241-252$.

9. Batters, E.A.L. On some New British Marine Algae. Ann. Bot. 1895, 9, 307-321. [CrossRef]

10. Saunders, G.W.; Jackson, C.; Salomaki, E. Phylogenetic analyses of transcriptome data resolve familial assignments for genera of the red-algal Acrochaetiales-Palmariales Complex (Nemaliophycidae). Mol. Phylogenet. Evol. 2018, 119, 151-159. [CrossRef]

11. Skriptsova, A.; Kalita, T. A re-evaluation of Palmaria (Palmariaceae, Rhodophyta) in the North-West Pacific. Eur. J. Phycol. 2020, 55, 266-274. [CrossRef]

12. Araújo, P.G.; Araújo, P.G.; Schmidt Éder, C.; Kreusch, M.G.; Kano, C.H.; Guimarães, S.M.; Bouzon, Z.L.; Fujii, M.; Yokoya, N.S. Ultrastructural, morphological, and molecular characterization of Colaconema infestans (Colaconematales, Rhodophyta) and its host Kappaphycus alvarezii (Gigartinales, Rhodophyta) cultivated in the Brazilian tropical region. Environ. Boil. Fishes 2014, 26, 1953-1961. [CrossRef]

13. Montoya, V.; Meynard, A.; Contreras-Porcia, L.; Contador, C.B. Molecular identification, growth, and reproduction of Colaconema daviesii (Rhodophyta; Colaconematales) endophyte of the edible red seaweed Chondracanthus chamissoi. Environ. Boil. Fishes 2020, 32, 3533-3542. [CrossRef]

14. Wynne, M.; Schneider, C. Colaconema basiramosum sp. nov (Colaconemataceae, Rhodophyta) from the Sultanate of Oman, Northern Arabian Sea. Cryptogam. Algol. 2008, 29, 69-80.

15. Shih, C.-C.; Hwang, H.-R.; Chang, C.-I.; Su, H.-M.; Chen, P.-C.; Kuo, H.-M.; Li, P.-J.; Tsui, K.-H.; Lin, Y.-C.; Huang, S.-Y.; et al. Anti-Inflammatory and Antinociceptive Effects of Ethyl Acetate Fraction of an Edible Red Macroalgae Sarcodia ceylanica. Int. J. Mol. Sci. 2017, 18, 2437. [CrossRef] [PubMed]

16. Rodríguez-Prieto, C.; De Clerck, O.; Kitayama, T.; Lin, S.-M. Systematic revision of the widespread species Sarcodia ceylanica (Sarcodiaceae, Rhodophyta) in the Indo-Pacific Oceans, including S. suiae sp. nov. Phycologia 2017, 56, 63-76. [CrossRef]

17. Provasoli, L. Media and Prospects for the Cultivation of Marine Algae. In Proceedings of the US-Japan Conference, Hakone, Japan, 12-15 September 1968; pp. 63-75.

18. Freshwater, D.W.; Rueness, J. Phylogenetic relationships of some European Gelidium (Gelidiales, Rhodophyta) species, based on rbcL nucleotide sequence analysis. Phycologia 1994, 33, 187-194. [CrossRef]

19. Lin, S.-M.; Fredericq, S.; Hommersand, M.H. Systematics of the Delesseriaceae (Ceramiales, Rhodophyta) based on large subunit rDNA and rbcl sequences, including the phycodryoideae, subfam. Nov. J. Phycol. 2001, 37, 881-899. [CrossRef]

20. Saunders, G.W. Applying DNA barcoding to red macroalgae: A preliminary appraisal holds promise for future applications. Philos. Trans. R. Soc. B Biol. Sci. 2005, 360, 1879-1888. [CrossRef]

21. Edgar, R.C. MUSCLE: Multiple sequence alignment with high accuracy and high throughput. Nucleic Acids Res. 2004, 32, 1792-1797. [CrossRef]

22. Kumar, S.; Stecher, G.; Li, M.; Knyaz, C.; Tamura, K. MEGA X: Molecular Evolutionary Genetics Analysis across Computing Platforms. Mol. Biol. Evol. 2018, 35, 1547-1549. [CrossRef] 
23. Hall, T.A. BioEdit: A user-friendly biological sequence alignment editor and analysis program for Windows 95/98/NT. Nucleic Acids Symp. Ser. 1999, 41, 95-98.

24. Trifinopoulos, J.; Nguyen, L.-T.; Von Haeseler, A.; Minh, B.Q. W-IQ-TREE: A fast online phylogenetic tool for maximum likelihood analysis. Nucleic Acids Res. 2016, 44, W232-W235. [CrossRef]

25. Rambaut, A. FigTree. Version 1.4.2 (Inst. Evol. Biol., Univ. Edinburgh, 2014). Available online: http://tree.bio.ed.ac.uk/software/ figtree/(accessed on 1 February 2021).

26. Nguyen, L.-T.; Schmidt, H.A.; Von Haeseler, A.; Minh, B.Q. IQ-TREE: A Fast and Effective Stochastic Algorithm for Estimating Maximum-Likelihood Phylogenies. Mol. Biol. Evol. 2015, 32, 268-274. [CrossRef] [PubMed]

27. Ronquist, F.; Teslenko, M.; Van Der Mark, P.; Ayres, D.L.; Darling, A.; Hoehna, S.; Larget, B.; Liu, L.; Suchard, M.A.; Huelsenbeck, J.P. MrBayes 3.2: Efficient Bayesian Phylogenetic Inference and Model Choice Across a Large Model Space. Syst. Biol. 2012, 61, 539-542. [CrossRef] [PubMed]

28. Garbary, D. The Effects of Temperature on the Growth and Morphology of Some Audouinella Spp. (Acrochaetiaceae, Rhodophyta). Bot. Mar. 1979, 22, 493-498. [CrossRef]

29. Tan, P.-L.; Lim, P.-E.; Lin, S.-M.; Phang, S.-M. Halymenia johorensis sp. nov. (Halymeniaceae, Rhodophyta), a new foliose red algal species from Malaysia. Environ. Boil. Fishes 2018, 30, 187-195. [CrossRef]

30. Boo, G.H.; Kim, K.M. A new species of marine algae from Korea based on morphology and molecular data: Gelidium palmatum sp. nov. (Gelidiales, Rhodophyta). ALGAE 2020, 35, 33-43. [CrossRef]

31. Bentall, G.B.; Rosen, B.H.; Kunz, J.M.; Miller, M.A.; Saunders, G.W.; Laroche, N.L. Characterization of the putatively introduced red alga Acrochaetium secundatum (Acrochaetiales, Rhodophyta) growing epizoically on the pelage of southern sea otters (Enhydra lutris nereis). Mar. Mammal Sci. 2015, 32, 753-764. [CrossRef]

32. Andrews, J.H. Pathology of seaweeds: Current status and future prospects. Cell. Mol. Life Sci. 1979, 35, 429. [CrossRef]

33. Correa, J.; McLachlan, J. Endophytic algae of Chondrus crispus (Rhodophyta). IV Effects on the host following infections by Acrochaete operculata and A. heteroclada (Chlorophyta). Mar. Ecol. Prog. Ser. 1992, 81, 73-87. [CrossRef]

34. González, M.A.; Goff, L.J. The red algal ekpiphytes microcladia coulteri and m. californica (rhodophyceae, ceramiaceae). J. Phycol. 1989, 25, 558-567. [CrossRef]

35. Bouzon, Z.L.; Ferreira, E.C.; dos Santos, R.W.; Scherner, F.; Horta, P.A.; Maraschin, M.; Schmidt, E.C. Influences of cadmium on fine structure and metabolism of Hypnea musciformis (Rhodophyta, Gigartinales) cultivated in vitro. Protoplasma 2011, 249, 637-650. [CrossRef] [PubMed]

36. Vairappan, C.S.; Chung, C.S.; Hurtado, A.Q.; Soya, F.E.; Lhonneur, G.B.; Critchley, A. Distribution and symptoms of epiphyte infection in major carrageenophyte-producing farms. In Proceedings of the 19th International Seaweed Symposium, Kobe, Japan, 26-31 March 2007; Borowitzka, M.A., Critchley, A.T., Kraan, S., Peters, A., Sjøtun, K., Notoya, M., Eds.; Springer: Dordrecht, The Netherlands, 2009; pp. 27-33. 